\title{
STRATEGI PEMASARAN PRODUK KECAP IKAN (Studi Kasus pada UP2KS Sari Laha di Kota Ternate)
}

\author{
Yonete Maya Tupamahu \\ Staf Pengajar Faperta UMMU-Ternate, e-mail: ymtup@yahoo.co.id
}

\begin{abstract}
ABSTRAK
Penelitian dilakukan di UP2KS Sari Laha bertujuan menganalisis kondisi lingkungan internal (kekuatan dan kelemahan) dan lingkungan eksternal (peluang dan ancaman) pada pemasaran kecap ikan dan merumuskan strategi pemasaran yang tepat bagi agroindustri kecap ikan. Penelitian menggunakan formulasi matriks IFE dan EFE, matriks IE, dan matriks SWOT. Hasil penelitian menunjukkan bahwa kekuatan agroindustri kecap ikan adalah produk memiliki ciri khas dan tenaga kerja terampil dan berpengalaman. Kelemahan agroindustri kecap ikan adalah proses produksi secara manual, sederhana, dan tidak kontinu; produk belum distandarisasi, kemasan kurang menarik, promosi produk belum intensif dilakukan, dan harga produk relatif lebih mahal. Peluang agroindustri adalah pangsa pasar masih lokal, bahan baku dan bahan penolong tersedia dan mudah diperoleh, dan adanya dukungan pemerintah dan instansi terkait lainnya. Ancaman agroindustri adalah banyaknya produk substitusi yang lebih murah, dan meningkatnya pengetahuan konsumen mengenai produk. Strategi berdasar analisis matriks Internal-Eksternal adalah strategi intensif, sedangkan analisis matriks SWOT menghasilkan empat alternatif strategi yaitu: Strategi SO yaitu perluasan usaha melalui pengembangan pasar dan meningkatkan produksi; Strategi WO yaitu meningkatkan mutu produk melalui proses standarisasi yang baku dan perbaikan teknologi produksi, kemasan, serta promosi ke daerah potensial lainnya, dengan melakukan kerja sama dengan pemerintah/ instansi terkait; Strategi ST yaitu pengembangan produk serta penentuan harga yang dapat bersaing dengan produk lainnya; dan Strategi WT yaitu melakukan pengamatan lingkungan melalui pencarian peluang pemasaran.
\end{abstract}

Kata Kunci: Strategi pemasaran, produk, kecap ikan

\section{PENDAHULUAN}

\subsection{Latar Belakang}

ikan merupakan salah satu produk pangan. yang dapat berperan sebagai sumber protein, tetapi kecap ikan sangat jarang atau bahkan tidak dikonsumsi secara langsung tetapi umumnya dijadikan bahan penyerta atau pemberi cita rasa pada masakan tertentu. Kecap ikan, seperti halnya kecap dengan bahan baku kedele lebih berfungsi sebagai penyedap masakan (Anonim, 2010).

Konsumen kecap ikan adalah rumah tangga, restoran/hotel, serta industri catering. Belum ada data statistik mengenai kebutuhan atau permintaan terhadap produk kecap ikan, akan tetapi dapat dipastikan bahwa permintaan atau kebutuhan terhadap produk ini selalu ada. Mengingat penggunaan kecap ikan pada berbagai menu makanan, maka tingkat dan perkembangan permintaan terhadap kecap ikan adalah sebanding dengan perkembangan industri restoran/hotel dan industri catering serta konsumsi rumah tangga (Anonim, 2010). Hal ini menjadi peluang pasar untuk berkembangnya agroindustri kecap ikan termasuk di Kota Ternate.

Data Disperindag Kota Ternate (2011) menunjukkan agroindustri kecap ikan di Ternate yang masih berproduksi hanya satu, yaitu Usaha Peningkatan Pendapatan Keluarga Sejahtera (UP2KS) Sari Laha yang beranggotakan kelompok ibu-ibu rumah 
tangga. Peluang ini juga ditunjang adanya tingkat konsumsi kecap secara umum berdasarkan Survei Biaya Hidup (BPS), dimana rata-rata konsumsi kecap untuk Kota Ternate adalah 1,13 botol per rumah tangga atau 0,22 botol per kapita. Data BPS (2010), menunjukkan jumlah penduduk Kota Ternate tahun 2009 sebesar 184.473 jiwa, maka potensi permintaan kecap adalah sekitar 40.584 botol per tahun, atau 111 botol per hari.

Jenis ikan yang merupakan bahan baku utama adalah ikan selar (Selaroides spp) atau nama lokalnya dikenal sebagai "ikan tude". Pengusaha beralasan bahwa ikan jenis ini memiliki cita rasa yang tinggi jika telah diproses menjadi kecap ikan. Bahan baku utama lainya adalah gula aren. Bahan baku utama maupun bahan penolong seperti bumbubumbu dan lainnya, diperoleh dari langganan yang menyediakan kebutuhan produksi di pasar lokal.

Kendala yang dihadapi oleh agroindustri kecap ikan yaitu kendala produksi dan pemasaran meliputi pertama, pengolahan kecap ikan masih bersifat manual dan sederhana. Kedua, proses produksi dalam satu bulan dilakukan hanya dua kali. Pembelian bahan baku ikan tude atau ikan selar dilakukan pada saat harga ikan murah untuk dua kali produksi. Sedangkan bahan baku gula aren pada proses produksi juga dibutuhkan dalam jumlah yang banyak (55 kg). Hal-hal tersebut diatas dapat pula berdampak bagi kinerja usaha dari aspek pendapatan.

Sedangkan kendala pemasaran meliputi pertama, pemasaran terbatas di Kota Ternate karena keterbatasan tenaga dan biaya pemasaran. Kedua, harga kecap ikan per botol lebih mahal dibandingkan produk kecap manis lainnya. Mahalnya harga kecap ikan ini tentunya dapat mempengaruhi pembeli, dimana pembeli akan memilih produk sejenis lainnya yang lebih murah. Pemasaran merupakan salah satu unsur penting diantara kegiatan pokok yang dilakukan oleh pengusaha dalam menentukan sukses suatu organisasi bisnis demi kelangsungan hidup, berkembang dan memperoleh suatu keuntungan. Berkembanganya teknologi, kuatnya posisi tawar-menawar (bargaining power) pelanggan dan banyaknya pesaing yang memasuki pasar, maka pengusaha harus meningkatkan kemampuan sumber daya manusianya dalam mengelola bidang pemasaran dan penetapan keputusan strategi pemasaran yang tepat.

\subsection{Tujuan Penelitian}

Penelitian ini memiliki tujuan sebagai berikut :

1. Menganalisis kondisi lingkungan internal (kekuatan dan kelemahan) dan lingkungan eksternal (peluang dan ancaman) pada pemasaran kecap ikan.

2. Merumuskan strategi pemasaran yang tepat bagi agroindustri kecap ikan.

\section{METODE PENELITIAN}

\subsection{Metode Penentuan Lokasi}

Lokasi penelitian ditentukan secara sengaja (purposive) yaitu UP2KS Sari Laha di Kelurahan Kalumpang Kota Ternate. Pemilihan lokasi ini berdasarkan pertimbangan bahwa UP2KS Sari Laha merupakan satu-satunya produsen kecap ikan di Kota Ternate. Penelitian ini dilaksanakan pada bulan Juni 2012.

\subsection{Metode Pengumpulan Data}

Penelitian ini menggunakan dua jenis data yaitu data primer dan data sekunder. Data primer diperoleh secara langsung dengan melakukan wawancara menggunakan daftar pertanyaan atau kuisioner yang telah dipersiapkan terlebih dahulu. Data yang dikumpulkan mengenai data perusahan dan strategi dalam melakukan usaha tersebut, serta data lainnya. Responden yang diwawancara sebanyak 3 orang, yaitu 1 orang ketua kelompok, 1 orang anggota bagian produksi, dan 1 orang bagian pemasaran. Setiap responden memiliki bobot dan pengaruh yang sama dalam penentuan skor dan factor-faktor kunci yang terdapat dalam penelitian ini. Data sekunder diperoleh dari berbagai instansi terkait yang berhubungan langsung dengan penelitian, buku dan internet.

\subsection{Metode Analisis Data}

Untuk menjawab tujuan penelitian pertama maka digunakan formulasi Matriks IFE dan EFE. Matriks Internal Factor Evaluation 
(IFE) digunakan untuk mengetahui faktorfaktor internal perusahaan berkaitan dengan kekuatan dan kelemahan yang dianggap penting. Matriks External Factor Evaluation (EFE) digunakan untuk meringkas dan mengevaluasi informasi tentang lingkungan eksternal yang dianalisis dengan cara mengukur sejauh mana peluang dan ancaman mempengaruhi perusahaan. Secara lengkap tersaji pada Tabel 1 dan Tabel 2.

Tabel 1. Matriks Internal Factor Evaluation (IFE)

\begin{tabular}{llll}
\multicolumn{1}{c}{ Faktor Kunci Eksternal } & Bobot & Rating & Skor \\
\hline Kekuatan (Strengths) & & \\
- & & \\
- & \\
\hline Kelemahan (Weaknessess) & 1,00 \\
\hline
\end{tabular}

Sumber : David, 2006

Tabel 2. Matriks External Factor Evaluation (EFE)

\begin{tabular}{llll}
\multicolumn{1}{c}{ Faktor Kunci Eksternal } & Bobot & Rating & Skor \\
\hline Peluang (Opportunity) & & \\
- & & \\
- & & \\
\hline Ancaman (Threats) & & \\
- & 1,00 & \\
- & & \\
\hline
\end{tabular}

Sumber : David, 2006

Matriks IFE dan EFE dapat dikembangkan menurut tahapan berikut :

1. Menyusun daftar kekuatan, kelemahan, peluang dan ancaman pada matriks.

2. Menentukan bobot setiap faktor internal maupun ekternal yang telah dianalisis dilakukan dengan cara mengajukan faktor tersebut kepada agroindustri dengan menggunakan metode Paired Comparison. Metode ini digunakan untuk memberikan penilaian terhadap bobot setiap penentu internal maupun eksternal perusahaan.
Untuk menentukan bobot setiap variabel digunakan skala 1, 2, dan 3. Skala yang digunakan dalam pengisian kolom yaitu :

1 = Jika indikator horizontal kurang penting daripada indikator vertikal

$2=$ Jika indikator horizontal sama penting daripada indikator vertikal

3 = Jika indikator horizontal lebih penting daripada indikator vertikal

Bentuk penilaian bobot dapat dilihat pada Tabel 3 dan Tabel 4 :

Tabel 3. Penilaian Bobot Faktor Internal

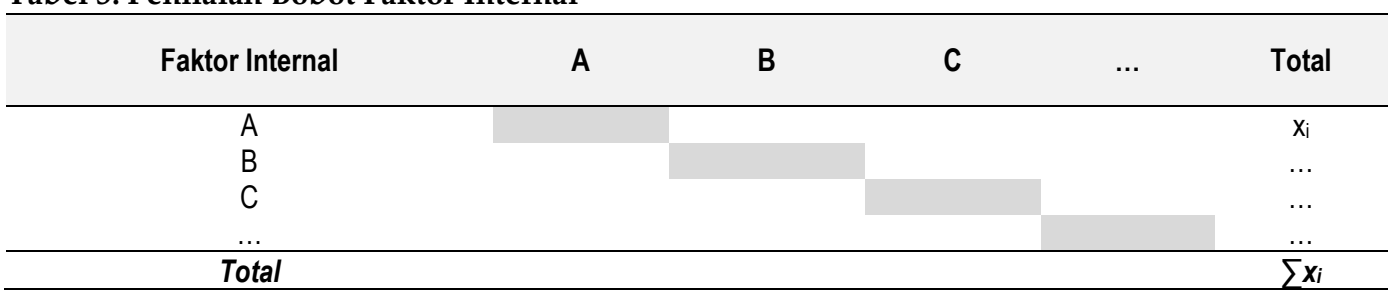


Tabel 4. Penilaian Bobot Faktor Eksternal

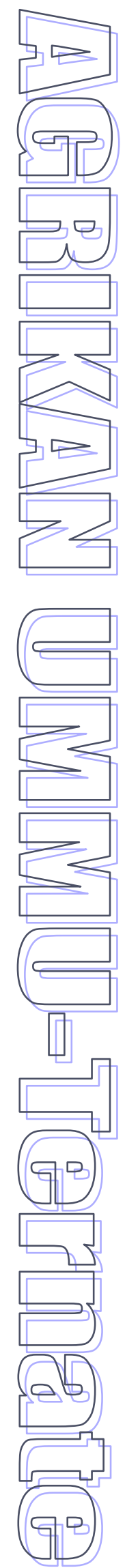

\begin{tabular}{|c|c|c|c|c|c|}
\hline Faktor Eksternal & A & B & C & $\ldots$ & Total \\
\hline A & & & & & $\mathbf{X} \mathbf{i}$ \\
\hline B & & & & & $\ldots$ \\
\hline C & & & & & $\begin{array}{l}\cdots \\
\cdots\end{array}$ \\
\hline$\ldots$ & & & & & $\ldots$ \\
\hline Total & & & & & $\sum x_{i}$ \\
\hline
\end{tabular}

Bobot setiap variabel diperoleh dengan menentukan rata-rata dari setiap variabel terhadap jumlah nilai keseluruhan variabel dengan menggunakan rumus:

$$
a_{i}=\frac{x_{i}}{\sum_{i=1}^{n} x_{i}}
$$

Dimana :

$$
\begin{array}{ll}
\mathrm{ai}_{\mathrm{i}} & =\text { bobot variabel ke-i } \\
\mathrm{x}_{\mathrm{i}} & =\text { nilai variabel ke-i } \\
\mathrm{i} & =1,2,3, \ldots, \mathrm{n} \\
\mathrm{n} & =\text { jumlah variable }
\end{array}
$$

3. Memberikan rating 1 sampai 4 untuk masing-masing matriks IFE dan EFE. Skala nilai yang digunakan untuk kekuatan pada matriks IFE yaitu 1= Kecil, 2 = Sedang, 3 = Besar dan 4 = Sangat besar. Untuk faktor kekuatan skala nilai yang digunakan yaitu 4 dan 3, dimana 4 merupakan faktor kekuatan utama agroindustri dan 3 jika faktor kekuatan tersebut bukan merupakan kekuatan utama agroindustri. Sedangkan untuk faktor kelemahan skala yang digunakan adalah 1 dan 2, dimana skala 1 merupakan kelemahan utama agroindustri dan skala 2 merupakan bukan kelemahan utama agroindustri.

Sedangkan rating yang diberikan pada matriks EFE mengidentifikasikan seberapa efektif agroindustri merespon peluang dan ancaman. Skala nilai yang digunakan untuk peluang dan ancaman pada matriks EFE yaitu ; 1 = Rendah, 2 = sedang, 3 = Tinggi, 4 = Sangat tinggi. Rating yang diberikan pada peluang yaitu skala 1 sampai 4, dimana skala 4 mengidikasikan bahwa agroindustri merespon dengan cara yang sangat tinggi terhadap peluang yang ada dan menghindari ancaman. Skala 3 jika kemampuan agroindustri dalam memanfaatkan peluang tinggi. Skala 2 mengindikasikan jika kemampuan agriindustri dalam memanfaatkan peluang sedang dan skala 1 mengidikasikan bahwa kemampuan agroindustri dalam memanfaatkan peluang rendah. Sedangkan pemberian rating untuk faktor ancaman kebalikan skala yang digunakan yaitu 1 sampai 4 . Skala 1 mengindikasikan bahwa jika kemampuan agroindustri dalam mengatasi ancaman rendah. Skala 2 mengindikasikan bahwa jika kemampuan agroindustri dalam mengatasi ancaman sedang. Skala 3 mengindikasikan bahwa jika kemampuan agroindustri dalam mengatasi ancaman tinggi dan skala 4 mengindikasikan bahwa jika kemampuan agroindustri dalam mengatasi ancaman sangat tinggi.

4. Mengalikan nilai bobot dengan nilai rating untuk mendapatkan skor pembobotan

5. Menjumlahkan skor yang diperoleh, kemudian dijumlahkan untuk menentukan nilai total skor faktor internal dan eksternal.

Untuk menjawab tujuan penelitian kedua dilakukan analisis dengan matriks Internal-Eksternal dan SWOT.

1. Matriks Internal-Eksternal (IE)

Parameter yang digunakan meliputi parameter kekuatan internal perusahaan dan pengaruh eksternal yang dihadapi. Matriks IE menempatkan berbagai divisi dari organisasi dalam sembilan sel. Matriks IE didasarkan pada dua dimensi kunci yaitu total nilai IFE yang diberi bobot pada sumbu $x$ dan total nilai EFE yang diberi bobot pada sumbu $y$.

Pada sumbu $x$ matriks IE, total nilai IFE yang diberi bobot dari 1,0 sampai 1,99 menunjukkan posisi internal yang lemah; nilai dari 2,0 sampai 2,99 dianggap sedang dan nilai dari 3,0 sampai 4,0 kuat. Demikian pula pada sumbu $y$, total nilai EFE yang diberi bobot 1,0 sampai 1,99 menunjukkan posisi eksternal yang lemah; nilai 2,0 sampai 2,99 dianggap sedang dan nilai dari 3,0 sampai 4,0 kuat. Matriks IE dibagi menjadi tiga bagian utama, antara lain : 
- $\quad$ Sel I, II dan IV disebut tumbuh dan bina. Strategi paling tepat untuk semua divisi ini adalah strategi intensif (penetrasi pasar, pengembangan pasar, dan pengembangan produk) atau strategi integratif (integrasi kebelakang, depan dan horizontal).
- Sel III, V, dan VII disebut pertahankan dan pelihara (hold and maintain). Strategi terbaik dapat dikelola dengan strategi penetrasi pasar dan pengembangan produk.

Sel VI, VIII atau IX adalah panen dan divestasi.

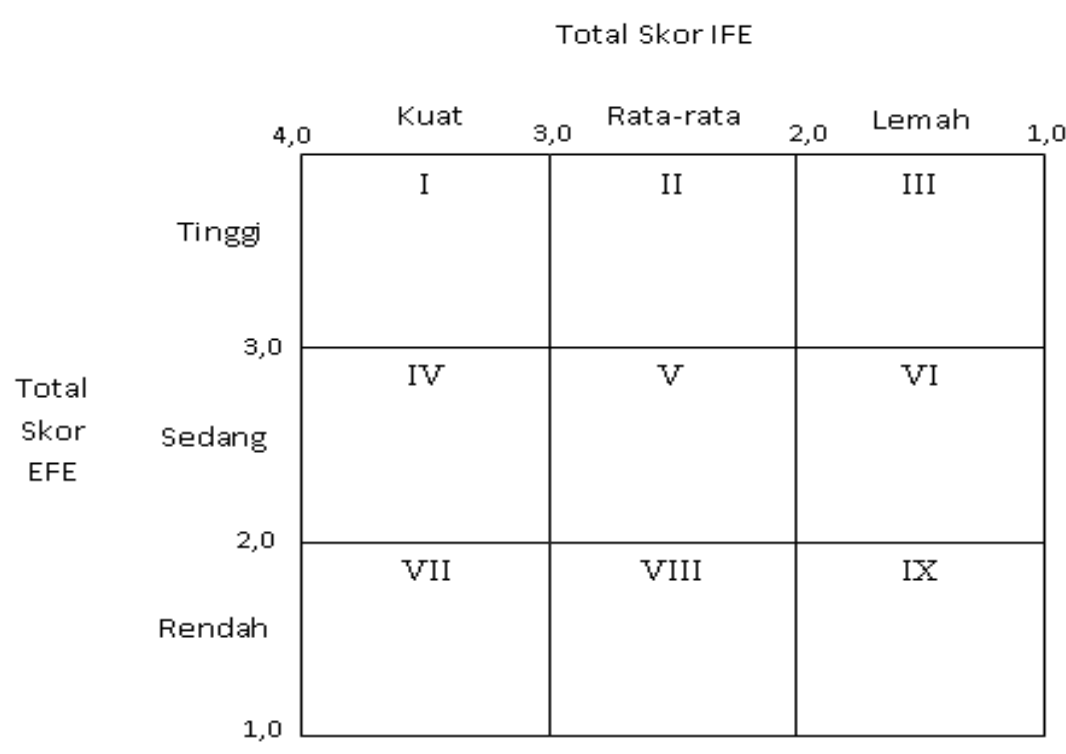

Gambar 1. Matriks Internal-Eksternal (IE)

(Sumber: David, 2006)

\section{Matriks SWOT}

Matriks SWOT merupakan identifikasi faktor-faktor untuk menetapkan strategi berdasarkan Strengths (kekuatan), Weaknesses (kelemahan), Opportunities (Peluang), dan Threats (Ancaman). Matriks SWOT digunakan untuk menyusun strategi perusahaan dan untuk menggambarkan peluang dan ancaman yang merupakan faktor eksternal yang dihadapi perusahaan disesuaikan dengan kelemahan dan kekuatan yang dimiliki. Matriks SWOT dapat dilihat pada Tabel 5.

Tabel 5. Matriks SWOT

\begin{tabular}{|c|c|c|}
\hline EFE & $\begin{array}{c}\text { Strenghts (S) } \\
\text { Susunlah daftar kekuatan-kekuatan } \\
\text { kunci internal perusahaan }\end{array}$ & $\begin{array}{c}\text { Weaknesses (W) } \\
\text { Susunlah daftar kelemahan- } \\
\text { kelemahan kunci internal } \\
\text { perusahaan }\end{array}$ \\
\hline Opportunities (0) & Strategi SO & Strategi WO \\
\hline $\begin{array}{l}\text { Susunlah daftar peluang-peluang } \\
\text { kunci eksternal perusahaan }\end{array}$ & $\begin{array}{l}\text { Hasilkan strategi-strategi yang } \\
\text { menggunakan kekuatan untuk } \\
\text { memanfaatkan peluang }\end{array}$ & $\begin{array}{l}\text { Hasilkan strategi-strategi yang } \\
\text { meminimalkan kelemahan untuk } \\
\text { memanfaatkan peluang }\end{array}$ \\
\hline Threaths ( $\mathrm{T})$ & Strategi ST & Strategi WS \\
\hline $\begin{array}{l}\text { Susunlah daftar ancaman-ancaman } \\
\text { kunci internal perusahaan }\end{array}$ & $\begin{array}{l}\text { Hasilkan strategi-strategi yang } \\
\text { menggunakan kekuatan untuk } \\
\text { mengatasi ancaman }\end{array}$ & $\begin{array}{l}\text { Hasilkan strategi-strategi yang } \\
\text { meminimalkan kelemahan dan } \\
\text { menghindari ancaman }\end{array}$ \\
\hline
\end{tabular}


Matriks SWOT menghasilkan empat sel kemungkinan alternatif strategi, yaitu strategi SO, strategi ST, strategi WO dan strategi WT (Umar, 2010):

1. Strategi SO

Strategi ini menggunakan kekuatan internal perusahaan untuk memanfaatkan peluang eksternal perusahaan. Organisasi umumnya akan menjalankan strategi WO, ST atau WT agar dapat mencapai situasi dimana mereka dapat menerapkan strategi SO.

2. Strategi ST

Strategi menggunakan kekuatan perusahaan untuk menghindari atau mengurangi pengaruh ancaman eksrenal. Dalam penilaian strategi ini, perubahan memberikan gambaran kekuatan yang dimiliki diiringi dengan mengamati kemungkinan ancaman yang dihadapi dalam industri.

3. Strategi WO

Perusahaan menghadapi peluang eksternal kunci tetapi perusahaan memiliki kelemahan internal yang menghambatnya untuk mengeksploitasi peluang tersebut. Strategi bertujuan untuk memperbaiki kelemahan internal dengan memanfaatkan peluang eksternal.

4. Strategi WT

Strategi ini merupakan taktik defensif yang diarahkan pada pengurangan kelemahan internal dan menghindari ancaman eksternal. Sebuah perusahaan menghadapi berbagai ancaman eksternal dan kelemahan internal akan berada pada posisi yang tidak aman. Kenyataannya, perusahaan seperti itu mungkin harus berusaha bertahan hidup, bergabung, mengurangi ukuran, mendeklarasikan kebangkrutan atau memilih likuidasi.

\section{HASIL DAN PEMBAHASAN}

3.1. Analisis Faktor Internal dan Eksternal

Faktor-faktor yang menjadi kekuatan dan kelemahan agroindustri kecap ikan dapat dilihat pada Tabel 6.

Tabel 6. Faktor-Faktor Evaluasi Internal

\begin{tabular}{|c|c|c|c|c|}
\hline & Faktor Strategis & Bobot & Rating & Skor \\
\hline \multicolumn{5}{|c|}{ Kekuatan : } \\
\hline 1. & Produk memiliki ciri khas & 0,145 & 3,33 & 0,48 \\
\hline 2. & Tenaga kerja terampil dan berpengalaman & 0,145 & 3,33 & 0,48 \\
\hline \multicolumn{5}{|c|}{ Kelemahan : } \\
\hline 1. & $\begin{array}{l}\text { Proses produksi secara manual, sederhana, dan tidak } \\
\text { kontinu }\end{array}$ & 0,128 & 2,67 & 0,34 \\
\hline 2. & Produk belum distandarisasi & 0,172 & 2,00 & 0,34 \\
\hline 3. & Kemasan kurang menarik & 0,141 & 2,67 & 0,38 \\
\hline 4. & Promosi produk belum intensif dilakukan & 0,148 & 2,33 & 0,35 \\
\hline 5. & Harga produk relatif lebih mahal & 0,121 & 2,33 & 0,28 \\
\hline & Total & 1,00 & & 2,66 \\
\hline
\end{tabular}

Sumber : data primer diolah

Faktor strategis yang menjadi kekuatan agroindustri kecap ikan yaitu :

a. Produk memiliki ciri khas

Kecap ikan yang diproduksi telah dikenal oleh masyarakat dengan nama "Kecap Ikan Spesial Sari Laha". Kecap ikan yang dihasilkan menyerupai kecap manis pada umumnya tetapi berbahan baku rebusan daging ikan dan bumbu-bumbu lalu dimasukan ke dalam larutan gula aren. Kapasitas produksi sebanyak 90 botol untuk satu kali produksi, hal ini disebabkan terbatasnya ruang pemasaran yang hanya tersebar di Kota Ternate.

b. Tenaga kerja terampil dan berpengalaman

Tenaga kerja yang terlibat dalam kegiatan produksi adalah anggota kelompok UP2KS Sari Laha, yang terdiri dari ibu-ibu. Anggota kelompok berjumlah 10 orang (termasuk ketua kelompok), dengan pembagiaan tugas: 5 orang dibagian produksi, 2 dibagian pemasaran, 1 orang dibagian keuangan (bendahara) serta 1 orang dibagian pembukuan (sekretaris). Usaha ini mulai dirintis sejak tahun 1989 dan pada tahun 2000 
berkembang menjadi UP2KS Sari Laha. Ketua Kelompok telah mengikuti pelatihan dari Disperindagkop, Balai POM dan Pemerintah Daerah. Pelatihan yang diikuti antara lain mengenai manajemen usaha, pelatihan Good Manufacturing Practices (GMP), keamanan pangan, dan gugus kendali mutu.

Faktor-faktor strategis yang menjadi kelemahan agroindustri kecap ikan adalah:

c. Proses produksi secara manual, sederhana, dan tidak kontinu

Proses produksi dilakukan secara manual oleh kelompok ibu-ibu. Peralatan yang digunakan dalam proses pengolahan kecap ikan bersifat sederhana, yaitu: kompor sebagai alat untuk pemasakan bumbu-bumbu, wajan sebagai alat pemasakan gula aren, pengaduk sebagai alat untuk mengaduk proses pembuatan kecap ikan, cerek sebagai alat untuk menyaring hasil produksi kecap ikan, blender sebagai alat penghancur, pisau dan parang sebagai alat pencincang ikan, timbangan sebagai untuk menimbang bahan baku, ember sebagai alat untuk penampung air, saringan panci sebagai wadah untuk mendinginkan hasil rebusan kecap ikan, loyang untuk membersihkan ikan dan tempat penampung ikan, sikat sebagai alat untuk membersihkan botol, alat pres dan penutup botol.

Proses produksi dengan cara perebusan, tahapan prosesnya sebagai berikut:

1. Bahan baku ikan tude (ikan selar), gula aren dan bahan penolong (lengkuas, serei, kuning, jeruk nipis dan garam) yang telah disiapkan dibersihkan. Daging ikan dipisahkan dari tulangnya dan diambil dagingnya. Sedangkan bahan penolong diblender, disaring dan diperas, diambil sarinya.

2. Daging ikan yang sudah dibersihkan lalu dimasak, sari bumbu dimasukan kedalam wajan berisi daging ikan selama 2 jam.

3. Perebusan gula aren sampai mencair.

4. Cairan daging ikan dan sari bumbu dimasukan ke dalam larutan gula aren yang sudah dimasak lalu diaduk rata, didihkan, dan diaduk sampai mengental.

5. Cairan kecap ikan kemudian didinginkan, kemudian dimasukan ke dalam botol yang sudah disiapkan, ditutup, disegel dan diberi label kecap ikan.

6. Kecap ikan siap dipasarkan

Kelemahan dalam proses produksi secara manual adalah saat sari ikan dan bumbubumbu yang sudah masak disaring membutuhkan waktu yang lama, serta masih ada sari ikan dan bumbu yang tersisa. Produksi kecap ikan tidaklah kontinu karena hanya dilakukan 2 kali dalam seminggu, atau 8 kali dalam sebulan. Bilamana pada hari-hari raya keagamaan terjadi peningkatan produksi karena adanya pesanan.

d. Produk belum distandarisasi

Standarisasi adalah suatu ukuran tingkat mutu suatu produk dengan menggunakan standar warna, ukuran atau volume, bentuk, susunan, ukuran jumlah dan jenis unsur-unsur kandungan (zat-zat kandungan), kekuatan atau ketahanan, kadar air, rasa, tingkat kematangan, dan berbagai kriteria lainnya yang dapat dijadikan standar dasar mutu produk (Gumbira-Sa'id dan Intan, 2001).

Produk kecap ikan belumlah distandarisasi, dimana hasil akhir hanya ditentukan berdasarkan berdasarkan rasa dan aroma. Produsen kecap ikan belum memiliki standar mutu produk yang baku, yaitu komposisi bahan yang digunakan, lama dan suhu saat pemasakan, dan sterilisasi botol. Namun demikian produk kecap ikan ini telah terdaftar Departemen Kesehatan RI.

e. Kemasan kurang menarik

Pengemasan (packaging) merupakan semua kegiatan merancang dan memproduksi wadah untuk produk. Kemasan produk menyangkut tiga tingkat bahan, yaitu kemasan primer (botol), kemasan sekunder (kotak karton), dan kemasan pengiriman (kotak bergelombang). Banyak produk fisik harus dikemas dan diberi label. Kemasan yang dirancang dengan baik dapat menciptakan nilai kenyamanan bagi pelanggan dan nilai promosi bagi produsen. Akibatnya mereka dapat bertindak sebagai "siaran niaga lima menit" untuk produk tersebut (Kotler dan Keller, 2009).

Kemasan produk kecap ikan hanya berupa kemasan primer yaitu kecap yang diisi ke dalam botol berukuran $650 \mathrm{ml}$, diberi label bertuliskan nama dagang produk dengan dasar 
warna merah muda dan kuning, ditutup botol dan segel botol. Kotler dan Keller (2009) menyatakan label melakukan beberapa fungsi yaitu mengidentifikasi produk atau merek, menunjukkan kelas produk, menjelaskan produk: siapa pembuatnya, dimana dibuat, kapan dibuat, apa saja kandungannya, bagaimana digunakan, dan bagaimana menggunakannya secara aman, serta mempromosikan produk melalui grafik-grafik yang menarik.

f. Promosi produk belum intensif dilakukan Promosi adalah kegiatan mengkomunikasikan jasa dan produk, dan menganjurkan pelanggan sasaran untuk membelinya (Kotler dan Armstrong, 2001). Promosi merupakan aktivitas pemasaran yang berusaha menyebarkan informasi, mempengaruhi/membujuk atau mengingatkan pasar sasaran atas perusahaan dan produknya agar bersedia menerima, membeli dan loyal pada produk yang ditawarkan perusahaan yang bersangkutan.

Pengusaha melakukan promosi sendiri dan langsung ke konsumen. Promosi ini menurut Kotler dan Armstrong (2005) dikategorikan sebagai personal selling dimana komunikasi langsung (tatap muka) antara penjual dan calon pelanggan untuk memperkenalkan suatu produk kepada calon pelanggan dan membentuk pemahaman pelanggan terhadap produk sehingga mereka kemudian akan mencoba dan membelinya. Hal ini berkaitan terbatasnya tenaga pemasaran yaitu hanya 2 orang dan penjualan hanya di Kota Ternate.

g. Harga produk relatif lebih mahal

Harga didefenisikan sebagai sejumlah uang yang harus dibayar oleh pelanggan untuk mendapatkan produk (Kotler dan Amstrong, 2001). Kebanyakan perusahaan akan menentukan harga pada tingkat yang nantinya akan menghasilkan keuntungan setinggitingginya. Mereka memperkirakan bahwa permintaan dan biaya ada hubungannya dengan tingkat harga sehingga menetapkan tingkat harga tertentu untuk memperoleh keuntungan maksimal dan arus kas. Dalam hal ini, perusahaan lebih menekankan keuntungan jangka pendek (Catur, 2006).
Metode penetapan harga yang didasarkan pada biaya yang paling sederhana dan cocok bagi produsen adalah cost-plus pricing. Pada metode ini, produsen/penjual akan menentukan harga jual untuk satu unit barang ditambah suatu jumlah tertentu untuk menutup laba yang diinginkan. Laba yang diinginkan dalam konsep ini disebut margin (Kotler dan Armstrong, 2005).

Demikian pula pada agroindustri kecap ikan, produsen menetapkan harga berdasarkan biaya-biaya yang telah dikeluarkan dan besarnya keuntungan yang diharapkan terlebih. Hal ini disebabkan terbatasnya produksi hanya 2 kali/minggu sebanyak 180 botol. Biaya tetap yang dikeluarkan meliputi penyusutan alat yaitu: kompor, wajan, pengaduk, cerek, mesin blender, parang, pisau, timbangan, ember, saringan, panci, baskom, sikat, alat pres botol, serta biaya tetap lainnya listrik dan air. Sedangkan biaya variabel meliputi biaya bahan baku, bahan pelengkap, biaya lain-lain serta upah tenaga kerja. Total biaya produksi agroindustri kecap ikan untuk 1 kali produksi sebesar Rp 2.354.306. Berdasarkan biaya-biaya yang dikeluarkan, produsen menetapkan harga penjualan produk kecap manis ukuran $650 \mathrm{ml}$ sebesar Rp 30.000 per botol. Harga ini telah mengalami peningkatan karena meningkatnya harga bahan baku dan jika dibandingkan dengan produk sejenis maka harganya lebih tinggi.

Faktor-faktor yang menjadi peluang dan ancaman agroindustri kecap ikan dapat dilihat pada Tabel 7.

Faktor-faktor strategis yang menjadi peluang agroindustri adalah :

a. Pangsa pasar masih lokal

Pemasaran produk kecap ikan hanya terbatas di Kota Ternate pada pasar atau warung, toko swalayan dan bahkan perkantoran. Pemasaran dilakukan dengan cara diantar langsung ke rumah konsumen, ada juga datang langsung ke tempat produsen kecap ikan. Ada juga pemasaran keluar daerah namun hanya sebatas oleh-oleh atau pesanan sehingga jumlahnya sedikit. Secara lengkap tersaji pada Gambar 2. 
b. Bahan baku dan bahan penolong tersedia dan mudah diperoleh

Keberlangsungan sebuah usaha pengolahan kecap ikan haruslah di dukung oleh potensi sumberdaya kelautan di Kota Ternate. Dengan demikian ketersediaan bahan baku ikan dapat menopong pengembangan usaha kecap ikan. Pada dasarnya semua jenis ikan dapat digunakan sebagai bahan baku kecap ikan, akan tetapi untuk menjaga rasa maka, bahan baku yang digunakan adalah ikan tude (ikan selar) dan gula aren. Selain itu ada juga bahan penolong lainnya yaitu lengkuas, serei, kunyit, jeruk nipis dan garam, dan lainnya. Ketersediaan bahan baku di peroleh dari pasar setempat. Pengadaan bahan baku serta bahan penolong lainnya dilakukan setiap satu kali produksi.

c. Adanya dukungan pemerintah dan instansi terkait lainnya

Agroindustri kecap ikan UP2KS Sari Laha pernah mendapatkan bantuan dana dan peralatan usaha dari Kukesra dan Pos atau
Giro, Bank BNI Ternate, Perindakop, PPK Provinsi Maluku Utara, BKKBN, Koperasi, Bank Mandiri Ternate, Dinas Perikanan dan Kelautan dan Balai POM.

Modal usaha pada saat memulai usaha diperoleh dari pemerintah melalui program Inpres Desa tertinggal (1986) sebesar Rp 25.000 serta mendapatkan pinjaman dari BKKBN sebesar Rp 15.000.000 untuk kebutuhan peralatan produksi dan modal usaha. Selain itu, UP2KS juga mempeloleh pinjaman dari Koperasi di lingkup Disperindakop Kota Ternate sebesar Rp 5.000.000. Jangka waktu pinjaman dari BKKBN adalah 10 bulan, sedangkan koperasi jangka pinjamannya adalah 12 bulan. Kewajiban pinjaman tersebut sudah dipenuhi oleh UP2KS Sari Laha. Kondisi usaha agroindustri sekarang ini didak lagi mendapatkan bantuan dana dari pemerintah kota. Akan tetapi usaha yang dijalankan pada UP2KS Sari Laha saat ini telah memakai modal sendiri.

Tabel 7. Faktor-Faktor Evaluasi Eksternal

\begin{tabular}{llcc}
\hline \multicolumn{1}{c}{ Faktor Strategis } & Bobot & Rating & Skor \\
\hline Peluang: & & & \\
\hline 1. Pangsa pasar masih lokal & 0,183 & 3,67 & 0,67 \\
2. Bahan baku dan bahan penolong tersedia dan mudah & 0,182 & 2,67 & 0,49 \\
$\quad$ diperoleh & & 3,33 & 0,88 \\
3. Adanya dukungan pemerintah dan instansi terkait lainnya & 0,263 & & 0,64 \\
\hline Ancaman: & & 3,67 & 0,72 \\
\hline 1. Banyaknya produk substitusi yang lebih murah & 0,197 & 3,67 & $\mathbf{3 , 4 0}$ \\
2. Meningkatnya pengetahuan konsumen mengenai produk & $\mathbf{1 , 0 0}$ & & \\
\hline
\end{tabular}

Sumber : data primer diolah

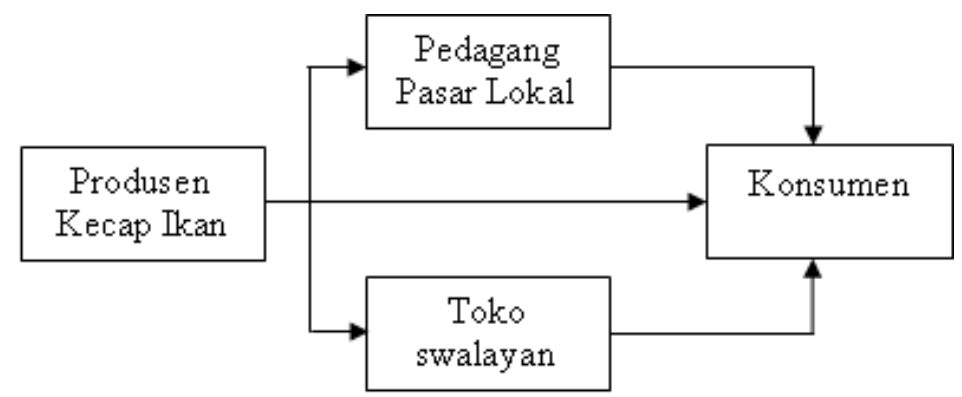

Gambar 2. Pemasaran Kecap Ikan UP2KS Sari Laha

Faktor-faktor strategis yang menjadi ancaman bagi agroindustri adalah :

a. Banyaknya produk substitusi yang lebih murah

Barang substitusi adalah barang yang memiliki manfaat dan kegunaan yang hampir sama dengan barang utamanya. Barang substitusi dekat adalah barang yang fungsi dan kegunaannya sama, hanya mungkin berbeda merek serta kemasan (Rosyidi, 2011). Dari segi fungsi/kegunaan, produk kecap ikan ini sama dengan kecap manis lainnya yang berbahan 
baku kedelai yaitu sebagai tambahan dalam masakan. Mahalnya harga kecap ikan (Rp 30.000 per botol ukuran $650 \mathrm{ml}$ ) dibandingkan produk sejenis, tentu akan mempengaruhi konsumen untuk membeli karena konsumen akan membeli produk yang harganya murah. Hal ini didukung oleh

Rosyidi (2011), jika peranan suatu barang dapat dengan mudah digantikan oleh barang lain, maka ketika harga naik, orang akan segera berpindah untuk menggunakan barang penggantinya itu dan meninggalkan pemakaian barang yang harganya telah naik itu

b. Meningkatnya pengetahuan konsumen mengenai produk

Pengetahuan mengenai produk mencakupi kesadaran akan kategori dan merek produk, atribut atau ciri produk, kepercayaan tentang kategori produk secara umum dan mengenai merek spesifik. (Engel, Blackwell, Miniard, 1990). Meningkatnya pengetahuan konsumen akan produk yang baik akan mempengaruhi konsumen untuk membeli, selain itu pengetahuan harga akan harga absolut dan harga relatif (jika dibandingkan dengan produk sejenis lain apakah harga lebih tinggi) dapat memberikan informasi untuk membimbing tindakan pemasaran.

\subsection{Analisis Matriks Internal-Eksternal (IE)}

Matriks IE diperoleh dengan memasukkan total skor rata-rata yang diperoleh dari matriks IFE dan EFE . Matriks ini bermanfaat untuk mengetahui posisi agroindustri sehingga dapat digunakan untuk menetapkan strategi yang sesuai untuk dijalankan. Total skor IFE sebesar 2,66 dimana agroindustri kecap ikan pada kondisi rata-rata dalam melakukan kegiatan pemasaran dan total skor EFE sebesar 3,40 memperlihatkan bahwa respon yang diberikan agroindustri terhadap lingkungan eksternal tergolong tinggi. Apabila total skor IFE dan EFE diposisikan pada matriks IE, maka posisi perusahaan saat ini berada pada sel II (Gambar 3).

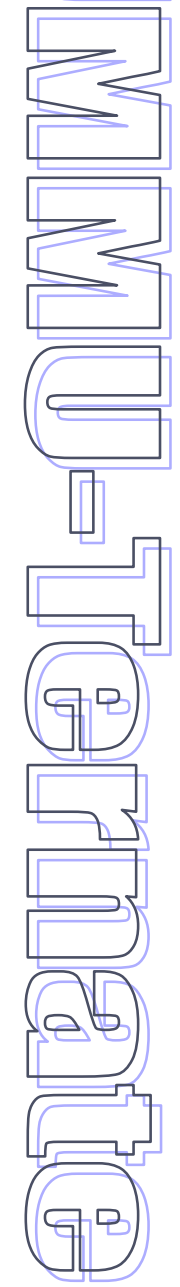

Total Skor IFE

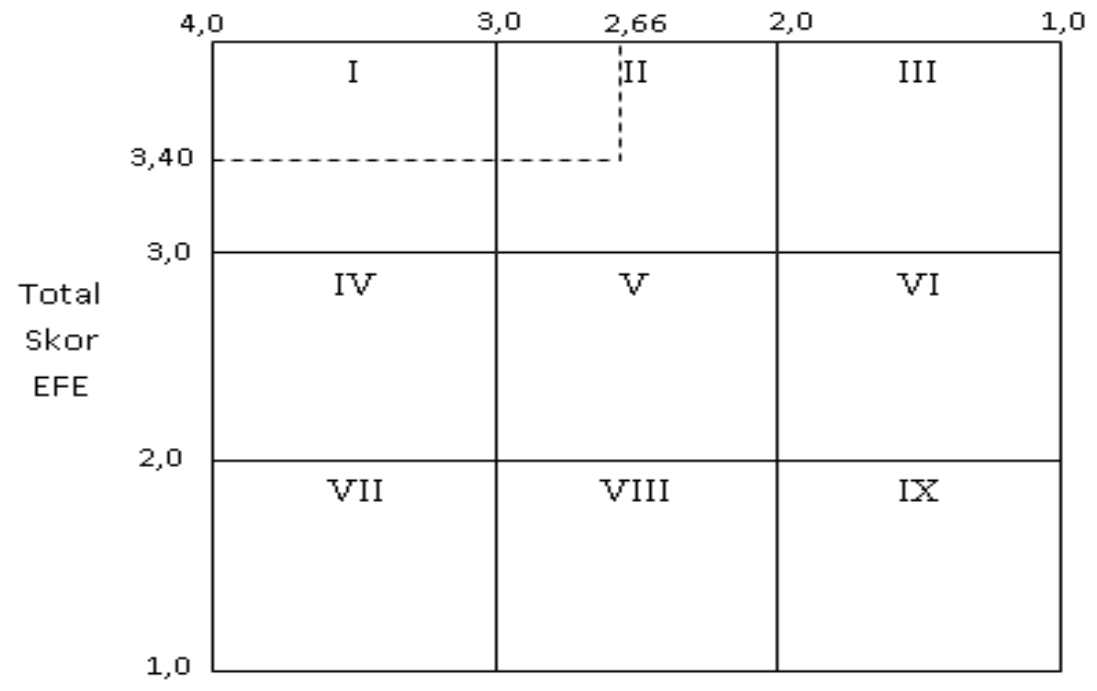

Gambar 3. Matriks IE Agroindustri Kecap Ikan

Pada sel II, strategi yang harus dijalankan oleh agroindustri adalah tumbuh dan kembangkan (growth and build). Strategi yang dapat dijalankan adalah strategi intensif (penetrasi pasar, pengembangan pasar dan pengembangan produk. David (2006) menyebutkan strategi penetrasi pasar berusaha meningkatkan pangsa pasar untuk produk saat ini melalui upaya pemasaran yang lebih besar, dengan meningkatkan tenaga penjual dan menawarkan promosi penjualan yang ekstensif. Pengembangan pasar melalui perkenalan produk yang ada saat ini ke area yang baru. Dan pengembangan produk adalah 
strategi yang mencari peningkatan penjualan dengan memperbaiki atau memodifikasi produk saat ini.

\subsection{Analisis Matriks SWOT}

Analisis matriks SWOT berfungsi untuk mengidentifikasikan secara sistematis kondisi internal dan eksternal yang mengembangkan empat alternative strategi berdasarkan kekuatan (strenght), kelemahan (Weakness), peluang (Opportunity) dan ancaman (Threat) bagi perusahaan. Tujuan dibuatnya matriks SWOT adalah untuk mengumpulkan sebanyak mungkin tindakan-tindakan strategi yang memungkinkan untuk digunakan perusahaan. Adanya analisis ini diharapkan perusahaan dapat menyusun strategi bersaing berdasarkan kombinasi antara faktor-faktor internal dan eksternal yang telah dimasukkan dalam matriks IFE dan EFE, sehingga akhirnya didapatkan suatu strategi yang sesuai berdasarkan posisi dan kondisi perusahaan (Tabel 8).

Alternatif strategi yang dapat dilakukan pada agroindustri kecap ikan antara lain :

1. Strategi SO

Pengembangan pasar sebagai strategi pertumbuhan agroindustri, dilakukan dengan cara mengidentifikasikan dan mengembangkan segmen-segmen pasar baru untuk produknya sekarang. Produsen dapat meningkatkan produksi dengan didukung tenaga kerja yang terampil dan tersedianya bahan baku utama dan bahan penolong, terlebih pemerintah/instansi lainnya.

\section{Strategi WO}

Mutu merupakan komponen utama dalam pembelian suatu produk karena agroindustri perlu meningkatkan mutu produk melalui proses standarisasi yang baku. Produk yang sudah memenuhi standar akan meningkatkan rasa aman konsumen terhadap produk yang dibelinya. Perbaikan teknologi produksi seperti pengadaan alat press untuk mengurangi kehilangan hasil serta efisien dari segi waktu. Perbaikan kemasan sehingga menarik serta memberikan informasi lengkap bagi konsumen, akan memengaruhi konsumen untuk membeli. Proses tersebut tadi dan kegiatan promosi juga perlu didukung oleh pemerintah/instansi terkait sehingga perlu dilakukan kerjasama yang berkesinambungan.

\section{Strategi ST}

Pengembangan produk dilakukan melalui perbaikan atau modifikasi produk saat ini sehingga dapat meningkatkan volume penjualan produk kecap ikan. Kemasan dijual dengan harga yang dapat dijangkau oleh konsumen sehingga dapat bersaing dengan produk lainnya. Produk kecap ikan yang memiliki cirri khas dapat menjadi faktor pendorong konsumen untuk membeli produk tersebut.

\section{Strategi WT}

Tujuan

dilakukan pengamatan lingkungan adalah melihat peluang pemasaran baru. Peluang pemasaran adalah wilayah kebutuhan atau potensi permintaan pembeli dimana agroindustri dapat menggarapnya secara menguntungkan. Ada tiga sumber utama peluang pasar, pertama adalah menyuplai sesuatu yang pasokannya kurang, kedua adalah memasok produk atau layanan yang sudah ada dengan cara baru atau lebih unggul, dan ketiga adalah membuat produk atau layanan yang sama sekali baru. Perbaikan produk dapat dilakukan dengan meminta saran dari konsumen dan meminta konsumen menggambarkan satu versi ideal dari produk atau layanan.

\section{KESIMPULAN DAN SARAN}

\subsection{Kesimpulan}

Berdasarkan hasil penelitian maka disimpulan hal-hal berikut :

1. a. Faktor-faktor internal yang merupakan kekuatan agroindustri kecap ikan adalah Produk memiliki ciri khas dan tenaga kerja terampil dan berpengalaman. Faktor-faktor internal yang merupakan kelemahan agroindustri kecap ikan adalah proses produksi secara manual, sederhana, dan tidak kontinu; produk belum distandarisasi, kemasan kurang menarik, promosi produk belum intensif dilakukan, dan harga produk relatif lebih mahal.

b. Faktor-faktor eksternal yang merupakan peluang agroindustri adalah pangsa pasar masih local, bahan baku 
dan bahan penolong tersedia dan mudah diperoleh, dan adanya dukungan pemerintah dan instansi terkait lainnya. Faktor-faktor eksternal yang merupakan ancaman bagi agroindustri adalah banyaknya produk substitusi yang lebih murah, dan meningkatnya pengetahuan konsumen mengenai produk.

2. a. Berdasarkan analisis matriks InternalEksternal maka strategi yang dapat dijalankan adalah strategi intensif meliputi penetrasi pengembangan pasar dan pengembangan produk.

b. Strategi SO dilakukan dengan perluasan usaha melalui pengembangan pasar dan meningkatkan produksi; Strategi WO dilakukan dengan meningkatkan mutu produk melalui proses standarisasi yang baku dan perbaikan teknologi produksi, kemasan, serta promosi ke daerah potensial lainnya, dengan melakukan kerja sama dengan pemerintah/ instansi terkait; Strategi ST yaitu melakukan pengembangan produk serta penentuan harga yang dapat bersaing dengan produk lainnya; dan Strategi WT yaitu melakukan pengamatan lingkungan melalui pencarian peluang pemasaran.

\subsection{Saran}

Berdasarkan hasil penelitian dapat disarankan hal-hal sebagai berikut :

1. Agroindustri dapat memilih strategi yang penting segera dilakukan yaitu strategi intensif dan strategi SO, diikuti strategi lainnya yaitu strategi WO, strategi ST dan strategi WT.

2. Agroindustri perlu melakukan kemitraan dengan pemerintah atau instansi lainnya secara berkesinambungan terkait dengan strategi pemasaran.

Tabel 8. Matriks SWOT Agroindustri Kecap Ikan

\begin{tabular}{|c|c|c|}
\hline 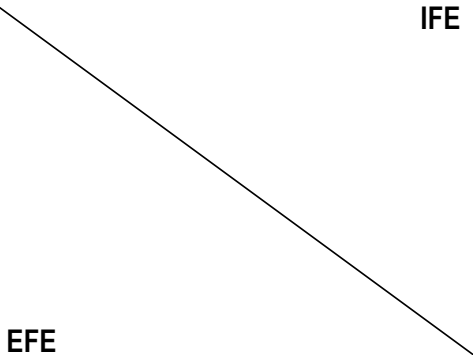 & $\begin{array}{l}\text { Kekuatan/Strenghts (S) } \\
\text { 1. Produk memiliki ciri khas } \\
\text { 2. Tenaga kerja terampil dan } \\
\text { berpengalaman }\end{array}$ & $\begin{array}{l}\text { Kelemahan/Weaknesses (W) } \\
\text { 1. Proses produksi secara manual, } \\
\text { sederhana, dan tidak kontinu } \\
\text { 2. Produk belum distandarisasi } \\
\text { 3. Kemasan kurang menarik } \\
\text { 4. Promosi produk belum intensif } \\
\text { 5. Hilakukan } \\
\text { 5. Harga produk relatif lebih mahal }\end{array}$ \\
\hline $\begin{array}{l}\text { Peluang/Opportunities (0) } \\
\text { 1. Pangsa pasar masih lokal } \\
\text { 2. Bahan baku dan bahan penolong } \\
\text { tersedia dan mudah diperoleh } \\
\text { 3. Adanya dukungan pemerintah } \\
\text { dan instansi terkait lainnya }\end{array}$ & $\begin{array}{l}\text { Strategi SO } \\
\text { Perluasan usaha melalui } \\
\text { pengembangan pasar dan } \\
\text { meningkatkan produksi (S1, S2,W1, } \\
\text { W2) }\end{array}$ & \begin{tabular}{l}
\multicolumn{1}{c}{ Strategi WO } \\
Meningkatkan mutu produk melalui \\
proses standarisasi yang baku dan \\
perbaikan teknologi produksi, \\
kemasan, serta promosi ke daerah \\
potensial lainnya, \\
dengan melakukan kerja sama \\
dengan pemerintah/ instansi terkait \\
(W1, W2, W3, W4, 01, 02, O3)
\end{tabular} \\
\hline $\begin{array}{l}\text { Ancaman/Threaths (T) } \\
\text { 1. Banyaknya produk substitusi } \\
\text { yang lebih murah } \\
\text { 2. Meningkatnya pengetahuan } \\
\text { konsumen mengenai produk }\end{array}$ & $\begin{array}{l}\text { Strategi ST } \\
\text { Melakukan pengembangan produk } \\
\text { serta penentuan harga yang dapat } \\
\text { bersaing dengan produk lainnya ( } \mathrm{S} 1 \text {, } \\
\mathrm{T} 1, \mathrm{~T} 2)\end{array}$ & $\begin{array}{l}\text { Strategi WT } \\
\text { Melakukan pengamatan lingkungan } \\
\text { melalui pencarian peluang } \\
\text { pemasaran (W1, W2, W3, W4, T1, T2, } \\
\text { T3) }\end{array}$ \\
\hline
\end{tabular}




\section{DAFTAR PUSTAKA}

Anonim, 2010. Pola Pembiayaan Usaha Kecil (PPUK) : Kecap Ikan. Bank Indonesia, Jakarta. Badan Pusat Statistik Kota Ternate, 2010. Kota Ternate Dalam Angka. Ternate.

Catur, E. Rismiati - Ig. Bomdan Suratno. 2006. Pemasaran Barang dan Jasa, Kanisius, Yogyakarta. David, F. R., 2006. Manajemen Strategis: Konsep. Buku 1, Edisi 10, Penerjemah I. S. Budi, Salemba Empat, Jakarta

Engel, J.F., R. D. Blackwell, P. W. Miniard, 1990. Perilaku Konsumen. Jilid 1, Edisi 12, Alihbahasa F.X. Budiyanto, Binarupa Aksara, Jakarta.

1990. Perilaku Konsumen. Jilid 2, Edisi 12, Alih Bahasa F.X. Budiyanto, Binarupa Aksara, Jakarta.

Gumbira-Sa'id, E. dan A.H. Intan, 2001. Manajemen Agribisnis. Ghalia Indonesia, Jakartta.

Kotler, P. dan G. Armstrong, 2001. Dasar-dasar Pemasaran. Jilid 1, Edisi Kesembilan. Alih Bahasa A. Sindoro dan B. Sarwiji, Jakarta. 2005. Prinsip-Prinsip Pemasaran, Erlangga, Jakarta

Kotler, P. dan K. L. Keller, 2009. Manajemen Pemasaran. Edisi 12, Jilid 1, Pengalih Bahasa Benyamin Molan, Indeks, Jakarta.

Rosyidi, S., 2011. Pengantar Teori Ekonomi: Pendekatan Pada Teori Ekonomi Mikro dan Makro. Edisi Revisi, Rajagrafindo Persada, Jakarta.

Umar, H., 2005. Desain Penelitian Manajemen Strategik. Rajagrafindo Persada, Jakarta. 